\title{
The CASBAH: a searchable database of caspase substrates
}

\author{
AU Lüthi ${ }^{1}$ and SJ Martin ${ }^{\star 1}$
}

Apoptosis is coordinated by members of the caspase family of aspartic acid-specific proteases. Other members of this protease family also play essential roles in inflammation where they participate in the maturation of pro-inflammatory cytokines. To date, almost 400 substrates for the apoptosis-associated caspases have been reported and there are likely to be hundreds more yet to be discovered. Thus, the fraction of the proteome that is degraded (the degradome) by caspases during the demolition phase of apoptosis appears to be quite substantial. Despite this, we still know surprisingly little concerning how caspases provoke some of the signature events in apoptosis, such as membrane phosphatidylserine externalization, cellular retraction, chromatin condensation and apoptotic body production. The inflammatory caspases appear to be much more specific proteases than those involved in apoptosis and only two confirmed substrates for these proteases have been described to date. Here, we have compiled a comprehensive list of caspase substrates and describe a searchable web resource (The Casbah; www.casbah.ie) which contains information pertaining to all currently known caspase substrates. We also discuss some of the unresolved issues relating to caspase-dependent events in apoptosis and inflammation.

Cell Death and Differentiation (2007) 14, 641-650. doi:10.1038/sj.cdd.4402103; published online 2 February 2007

Since the discovery that the major effectors of programmed cell death are members of the caspase family of proteases, significant efforts have been directed towards understanding the multifarious roles that members of this evolutionaryconserved family of proteases play in apoptosis. Although the mechanisms of activation of the worm, fly and mammalian caspases are now relatively well understood, ${ }^{1,2}$ much less is known about how these proteases contrive to kill cells. Although hundreds of mammalian caspase substrates have now been identified - and therein lies the root of the problem we still know surprisingly little about how caspases coordinate the terminal events in apoptosis that result in death of the cell.

\section{Discriminating Innocent Bystanders from Legitimate Targets}

For this overview, we have searched the literature for caspase substrates and have compiled a somewhat daunting list of 390 proteins that have been reported to be cleaved by caspases, either in vitro, during apoptosis or inflammation (see Supplementary Table 1). Owing to this profusion of caspase substrates, the major challenge now is to identify the subset of these proteins that have functional significance for the process of apoptosis and/or inflammation. Although it is within the bounds of possibility that all proteins that are cleaved by caspases during apoptosis contribute to the demise of the cell on some level, it seems highly unlikely that all caspase substrates play equally significant roles in this process. On the contrary, it seems rather more likely that many proteins are simply caught up in the proteolytic maelstrom that envelops a cell during apoptosis and become cleaved by caspases- by accident rather than design - during the terminal phase of cell death. Thus, the nub of the problem is to discriminate what we have previously termed the 'innocent bystanders' from the 'legitimate targets' of caspase-mediated attack. ${ }^{3}$

Unfortunately, there is no easy way to identify functionally important caspase substrates from the proteolytic noise that almost inevitably accompanies a process where several proteases become activated within a short time frame. ${ }^{4-6}$ Painstaking analysis of individual caspase substrates involving the mapping of precise caspase cleavage sites, the creation and expression of non-cleavable mutants and/or cleaved forms of the substrate, the generation of gene knockouts or non-cleavable knock-ins - is required to generate a definitive link between proteolysis of an individual substrate and a specific 'apoptotic parameter'. For the vast majority of substrates that have been described to date (see Supplementary Table 1), such analyses have not been carried out. Rather, the consequences of proteolysis of individual substrates has either been inferred or in some cases, the cleaved form of the substrate has been overexpressed and the functional effects of this have been evaluated in otherwise healthy cells. In many cases, we also await confirmation that putative caspase substrates are actually cleaved by caspases

\footnotetext{
${ }^{1}$ Molecular Cell Biology Laboratory, Department of Genetics, The Smurfit Institute, Trinity College, Dublin, Ireland

*Corresponding author: SJ Martin, Molecular Cell Biology Laboratory, Trinity College Dublin, The Smurfit Institute of Genetics, Dublin D2, Ireland. Tel: 35318961289 ; Fax: 3531679 8558; E-mail: martinsj@tcd.ie

Keywords: Apoptosis; caspases; caspase substrates; degradome; proteome

Abbreviations: RIP-1, receptor-interacting serine/threonine-protein kinase 1; ICAD, inhibitor of caspase-activated DNase; CAD, caspase-activated DNase; iPLA, calcium independent phospholipase $\mathrm{A}_{2}$

Received 16.11.06; revised 22.12.06; accepted 02.1.07; Edited by S Kumar; published online 02.2.07
} 
at physiological concentrations of enzyme. For example, the recently identified cytokine, IL-33, has been reported to be a substrate for caspase-1. ${ }^{7}$ However, the latter proposal is based solely upon the observation that this cytokine is cleaved in vitro by recombinant caspase- 1 at arbitrary concentrations of this enzyme. ${ }^{7}$

One way of approaching the question of whether a caspase substrate is potentially more relevant than others is to ask whether this protein is also cleaved by caspases in other species. However, this approach has not been adopted in many cases and has led to generalizations concerning the significance of some substrates for apoptosis that are unlikely to be borne out upon more detailed analysis. Although it is certainly possible that some caspase substrates may be cleaved in a species-specific manner, it seems implausible that the same functional endpoints are achieved through proteolysis of a completely different array of proteins in different species. This view is buttressed by observations that many of the same morphological endpoints are seen in apoptotic cells from organisms as divergent as flies and man. ${ }^{8}$ Thus, it is probable that a conserved cohort of caspase substrates are cleaved by worm, fly and mammalian caspases, and that these represent the legitimate targets that ensure controlled cell destruction, as well as the morphological and functional hallmarks of apoptosis.

Exceptions to the above are likely to be caspase substrates that play roles in signal transduction cascades that operate only in certain organisms. For example, nematodes do not appear to possess death receptors; therefore, signalling intermediates in death receptor pathways, such as BID and $\mathrm{RiP}-1$, which are important caspase substrates in mammals are not present in this organism. Similarly, it is also possible that tissue-specific proteins may be targeted by caspases to regulate some unique aspect of apoptosis in such tissues.

\section{Caspases are Required for the Apoptotic Phenotype}

There has been an ongoing debate as to whether caspases are essential for apoptosis of mammalian cells or whether other proteases can step into the breach to achieve the same end points when caspase activity is stymied. ${ }^{9-12}$ Some investigators hold the view that essentially similar cell death endpoints can be achieved regardless of whether caspase activity is muzzled. Under conditions where caspase activity is experimentally disabled - either through genetic inactivation of specific caspases or caspase-activating proteins such as Apaf-1 or through exposure of cells to poly-caspase inhibitors, such as Z-VAD-fmk - cell death still occurs in response to many pro-apoptotic triggers and this is taken as evidence that caspases are not required for apoptosis. However, in the vast majority (if not all) of these cases, the morphological end points seen when caspases are prevented from participating are not what are commonly regarded as hallmarks of apoptotic cell death. ${ }^{11,12}$ Rather, caspase inhibition typically converts the phenotype of the dying cell from apoptosis into necrosis. ${ }^{11,12}$

So why does caspase inhibition/inactivation fail to protect cells from stimuli that provoke apoptosis? In mammals, this is owing to events upstream of caspase activation that provoke the release of mitochondrial intermembrane space proteins such as cytochrome $c$. Although this does not apply to all pro-apoptotic stimuli (engagement of death receptors for example), it applys to stimuli where BH3-only proteins play instrumental roles in promoting mitochondrial permeabilisation and assembly of the Apaf-1/caspase- 9 apoptosome downstream. ${ }^{13}$ In such cases, owing to the rapid decline in mitochondrial function, most cells are irreversibly committed to die irrespective of whether caspases are activated downstream. However, in the absence of caspase activation, the phenotype of the resulting death is necrotic rather than apoptotic. The exception seems to be certain post-mitotic cells such as neurons and cardiomyocytes, as these cells can recover from mitochondrial permeabilisation as long as caspase activation is prevented downstream. ${ }^{14,15}$

In the case of the nematode worm, Caenorhabditis elegans, it is clear that the CED-3 caspase is essential for all developmental-related programmed cell deaths in this organism. ${ }^{16,17}$ Strong loss-of-function mutations in CED-3 block all programmed cell deaths in the worm, thereby illustrating that a default cell death programme is not present in this organism. Similar observations have also been made with respect to mutations in the CED-3 - activating adaptor molecule, CED-4. ${ }^{16}$

In the fruitfly, it is also the case that loss-of-function mutations associated with the CED-4 homologue, ARK (dApaf-1/HAC-1) ${ }^{18}$ or its caspase-binding partner, DRONC, lead to extensive disruption of the normal patterns of cell death that are seen during development. ${ }^{19-21}$ Furthermore, despite intensive genetic screening using both worm and fly, no other proteases have emerged as playing influential roles in programmed cell death in these organisms.

In mammals, there is also good genetic evidence to argue that caspases and their activators play central roles in apoptosis. To date, knockouts have been generated for the apoptosis-associated caspases, caspase-2, caspase-3, caspase-6, caspase-7, caspase-8 and caspase-9, as well as the caspase- 9 adaptor protein Apaf-1. ${ }^{22-24}$ In several of these cases, programmed cell death is severely disrupted and embryonic lethality is observed. However, as discussed above, mutation or inactivation of caspases rarely confers clonogenic rescue upon a cell owing to the fact that one of the most commonly utilised routes to apoptosis in mammals, the mitochondrial pathway, involves permeabilization of mitochondria before caspase activation. ${ }^{13}$ Because of this, blocking caspase activation downstream of mitochondrial outer membrane permeabilization is typically futile as cells die as a result of mitochondrial dysfunction. However, death without caspase participation rarely, if ever, manifests the normal spectrum of changes that define apoptosis. ${ }^{25}$ Nonetheless, some investigators have labeled this type of cell death 'atypical apoptosis' or 'caspase-independent apoptosis' or 'aponecrosis' which can give rise to misunderstandings concerning whether caspases are really required for apoptosis.

\section{Global Perspectives on Caspase-Mediated Substrate Proteolysis}

Given the embarassment of riches presented by approximately 400 mammalian caspase substrates that have now 
been described (see Supplemental Table 1), it is unfortunately not yet possible to paint a clear picture of how caspases achieve the sterotypical changes that are seen during apoptosis. Indeed because most of the known caspase substrates have been identified serendipituously, it is very likely that hundreds of additional caspase substrates are likely to emerge upon systematic proteomics-based analyses of the proteomes of apoptotic cells.

Although we have tabulated essentially all of the caspase substrates that have been reported in the literature to date, it is important to point out that many of these substrates are simply reported to be cleaved during apoptosis and data pertaining to their functional significance have yet to emerge. Moreover, in most cases the caspase cleavage sites within these proteins have not been mapped, nor has it been tested whether these proteins are also targeted for proteolysis by caspases in other mammalian species, such as the mouse. Therefore, the precise role of the majority of caspase substrates in apoptosis remains speculative, at best, and many are almost certainly insignificant for the completion of the process. However, some caspase substrates have been definitively linked to specific cell death end points as we will discuss below.

\section{The CASBAH: The CAspase Substrate DataBAse Homepage}

Because of the expanding list of caspase substrates, we have created an online database containing all of the reported mammalian caspase substrates (http://www. casbah.ie). This database is fully searchable and contains linkouts to the UniProt (the Universal Protein Resource) database, which contains extensive additional information on each protein. In addition, where the caspase cleavage site(s) with a substrate have been mapped, this information is included within the CASBAH entry, along with relevant references to the primary papers that first reported a particular caspase substrate. We hope that this will be a useful resource for investigators working in this area.

\section{Relative contributions of Caspases to Cell Demolition}

The majority of studies indicate that caspases are certainly not equal in terms of their ability to cleave cellular substrates. The apoptosis-associated initiator caspases (caspase -8, -9 and -10 and possibly also caspase-2) appear to be highly specific proteases that cleave few substrates apart from their own precursors and other caspases downstream. Apart from other caspases, the only well-established substrates for the initiator caspases, which have been identified to date, is the BH3-only protein BID and RIP kinase. BID is cleaved by caspases -8 and -10 upon stimulation of death receptors and plays an important role in the propagation of pro-apoptotic signals through promoting mitochondrial outer membrane permeabilization and cytochrome $c$ release. ${ }^{26,27}$ RIP is recruited to the tumour necrosis factor and Fas receptor complexes and controls nuclear factor-kappa $\mathrm{B}(\mathrm{NF} \kappa \mathrm{B})$ activation via recruitment of the regulatory subunit of the $I_{\kappa} B$ kinases complex. ${ }^{28,29}$ However, RIP can be inactivated through proteolysis by caspase- 8 and this facilitates propagation of the death signal as opposed to NF $\kappa \mathrm{B}$-mediated survival signals. ${ }^{28,29}$
There is little evidence that the initiator caspases can contribute to the generalised proteolysis seen during apoptosis. However, it is useful to point out that high (i.e. nonphysiological) concentrations of recombinant caspases will cleave practically any caspase substrate in vitro. Clearly, this does not offer proof that this protease is responsible for this event in vivo, although it is often implied that this is the case. So, which proteases are responsible for most of the substrate proteolysis seen during the demolition phase of apoptosis? Evidence from caspase-deficient cells and cell lines, as well as immunodepleted cell-free extracts, point towards caspase- 3 as the major effector caspase. ${ }^{25,30,31}$ Loss of caspase- 3 abolishes or dramatically delays the kinetics of the majority of substrate proteolysis seen during apoptosis. Thus, the vast majority of substrates listed in Supplementary Table 1 are most likely preferentially cleaved by caspase-3 during apoptosis. Caspase-7 possesses similar specificity to caspase-3 towards synthetic tetrapeptide substrates and these enzymes are sometimes regarded as functionally redundant. ${ }^{32,33}$ However, activity towards synthetic tetrapeptide-based substrates does not give information concerning interactions with full-length substrate proteins, particularly at surfaces outside of the catalytic pocket of the enzyme. Therefore, it is certainly plausible that caspases -3 and -7 exhibit distinct activities towards full length substrate proteins. Indeed, gene knockout and immunodepletion experiments argue that caspase-7 cannot readily substitute for the absence of caspase-3, although this may also relate to the relative expression levels of either caspase within cells. ${ }^{4,31,34-37}$

Few cellular substrates for caspase- 6 have been identified thus far. Although several substrates for caspase- 6 have been reported, the majority of these claims rest upon data generated in vitro using high concentrations of recombinant caspases. The most well-established substrate for caspase- 6 appears to be the nuclear lamins $A$ and $C,{ }^{31,38,39}$ whereas lamin $B$ is cleaved by caspase- $-3^{31}$ Caspase- 6 is also responsible for the proteolytic maturation of caspases -2 and -8 within the caspase cascade that is initiated downstream of assembly of the Apaf-1 apoptosome. ${ }^{4,40,41}$ However, loss of caspase- 6 appears to have no overt effect on developmental apoptosis. ${ }^{22,36}$ Thus, the contribution of caspase- 6 to the demolition phase of apoptosis remains enigmatic.

\section{How do Caspases Coordinate Apoptosis?}

Of the hundreds of caspase substrates that have been reported to date, a small subset of these have been convincingly linked with specific alterations to the cellular architecture that are generally accepted to be hallmarks of apoptosis. The list of these 'intended victims' is surprisingly short at present.

It is worth reminding ourselves that apoptosis is a morphologically defined mode of cell death that is associated with several distinct features. ${ }^{42,43}$ Of course, there are likely to be other modes of programmed cell death that display different characteristics, but these modes of cell death are, almost by definition, not apoptotic in nature. On the basis of the original studies of Kerr et al., ${ }^{42}$ apoptotic cells typically 
display pronounced compaction of chromatin and, in the majority of cases, the nucleus undergoes progressive fragmentation and dispersal throughout the cell body. The latter events are highly distinctive and can be completely blocked by inhibition of caspase activity. ${ }^{44,45}$ Studies on the serine/threonine kinase rho-associated kinase I (ROCK I) have strongly implicated this kinase in apoptosis-associated nuclear fragmentation (Figure 1). ${ }^{46,47}$ Caspase-mediated proteolysis of ROCK I leads to loss of the C-terminal autoinhibitory region of this molecule and produces a constitutively active kinase which is capable of contributing to myosin light chain phosphorylation and other events leading to increased actin-myosin contractility (Figure 1). This increased contractility of the actin cytoskeleton, in tandem with caspase-mediated proteolysis of the nuclear lamins that contribute to weakening of the nuclear envelope, ${ }^{48}$ has been linked with the dismembering of the nucleus into several fragments as typically occurs during apoptosis. ${ }^{46,47}$

Cells undergoing apoptosis also retract from neighbouring cells, losing contact with other cells and the substratum and usually undergo extensive plasma membrane blebbing which can also lead to collapse of the cell into numerous small fragments, termed apoptotic bodies. ${ }^{42}$ However, the produc- tion of apoptotic bodies seems to be very dependent on cell type, as some cell types fragment to a greater or lesser degree than others. Once again, neutralisation of caspase activity is a very efficient means of blocking apoptosis-associated cellular retraction, plasma membrane blebbing and apoptotic body production. ${ }^{30,49}$ Although it remains unclear precisely how caspases coordinate cellular retraction, this very likely relates to the ability of caspases to cleave several cytoskeletal proteins such as actin, tubulin, fodrin and vimentin. Many other proteins with structural roles within the cell are also cleaved during apoptosis (see Table 1) and it is likely that proteolysis of such proteins contributes to the dramatic morphological rearrangements that take place during this mode of cell death.

ROCK I has also been heavily implicated in the production of plasma membrane blebs during apoptosis, again through reorganisation of the actin-myosin cytoskeleton owing to the caspase-dependent loss of ROCK I-auto-inhibition (Figure 1). ${ }^{46,47,49,50}$ In agreement with this, depolymerisation of the actin cytoskeleton using fungal toxins efficiently abolishes the production of apoptotic bodies. ${ }^{51}$

Although not a morphological feature of apoptosis, one of the earliest biochemical signatures of this process to be

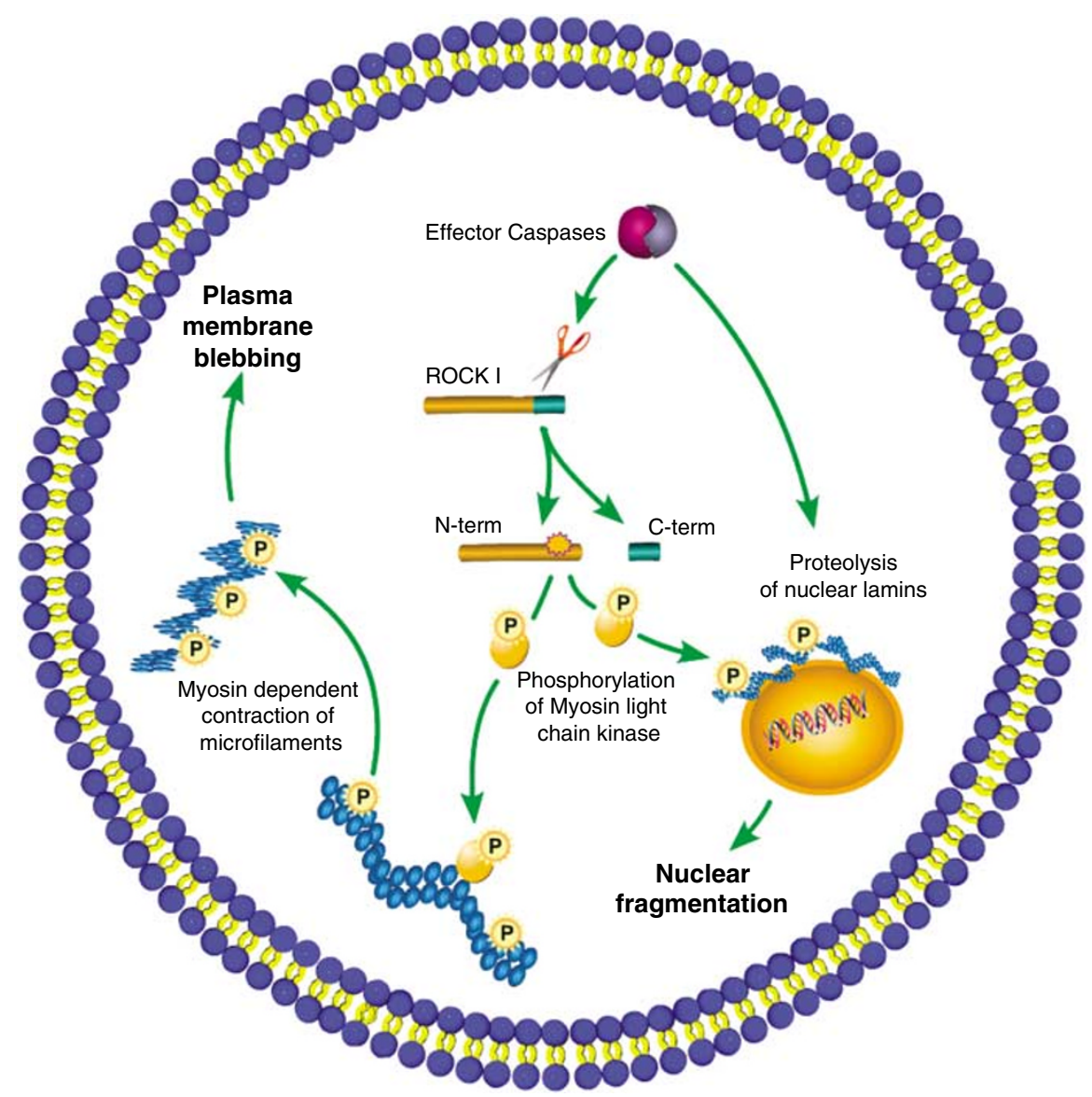

Figure 1 Caspase-dependent proteolysis of ROCK I contributes to plasma membrane blebbing and nuclear fragmentation. Caspase-dependent cleavage of ROCK I removes the regulatory $\mathrm{C}$ terminus of the molecule, resulting in a constitutively active kinase. Active ROCK I promotes phosphorylation of myosin light chain kinase which, in turn, regulates myosin-dependent actin rearrangements. Rearrangement of actin microfilaments can contribute to plasma membrane blebbing and, in tandem with caspasedependent cleavage of nuclear lamins, nuclear fragmentation 
Table 1 Caspase substrates: structural proteins

\begin{tabular}{|c|c|c|c|}
\hline Name & UniProt & Consequences of caspase-dependent proteolysis (proposed) & Site(s) \\
\hline $\begin{array}{l}\alpha \text {-Actin } \\
\beta \text {-Actin } \\
\alpha \text {-Actinin } \\
\alpha \text {-Adducin }\end{array}$ & $\begin{array}{l}\text { ACTC_HUMAN } \\
\text { ACTB_HUMAN } \\
\text { ACTN1_HUMAN } \\
\text { ADDA_HUMAN }\end{array}$ & $\begin{array}{l}\text { Putative: myofibrillar damage } \\
\text { Unknown } \\
\text { Putative: myofibrillar damage } \\
\text { Putative: reduction of adducin from adherens junctions and possibly } \\
\text { cell detachment }\end{array}$ & $\begin{array}{l}\text { Unknown } \\
\text { ELPD } \\
\text { Unknown } \\
\text { DDSD }\end{array}$ \\
\hline $\begin{array}{l}\text { Allx } \\
\text { BAP31 }\end{array}$ & $\begin{array}{l}\text { APC_HUMAN } \\
\text { BAP31_HUMAN }\end{array}$ & $\begin{array}{l}\text { Separates } \beta \text {-catenin binding region and armadillo repeat } \\
\text { Downregulation of surface CD9/CD80 and reduction of cell } \\
\text { attachment to fibronectin. }\end{array}$ & $\begin{array}{l}\text { DVID }^{777} \\
\text { AAVD }^{163}\end{array}$ \\
\hline ВАТЗ & BAT3_HUMAN & $\begin{array}{l}\text { Overexpressed C-terminal fragment leads to morphological changes } \\
\text { similar to apoptosis }\end{array}$ & DEQD ${ }^{1001}$ \\
\hline$\beta$-Catenin & CTNB1_HUMAN & Reduced $\alpha$-catenin binding. Putative: loss of cell adhesion & $\begin{array}{l}\text { YQDD }^{145}, \text { NDED }^{164}, \text { SYLD }^{32} \\
\text { ADID }^{83}, \text { TQFD }^{115}, \text { YPVD }^{751}\end{array}$ \\
\hline $\begin{array}{l}\text { Cadherin } 2 \\
\text { Cas }\end{array}$ & $\begin{array}{l}\text { CADH2_HUMAN } \\
\text { BCAR1_HUMAN/ } \\
\text { MOUSE }\end{array}$ & $\begin{array}{l}\text { Putative: loss of cell adhesion } \\
\text { Contributes to disassembly of focal adhesion complexes }\end{array}$ & $\begin{array}{l}\text { Unknown } \\
\text { DVPD }^{416}, \text { DSPD }^{748}\end{array}$ \\
\hline CALM & Q6GMQ6_HUMAN & Unknown & Unknown \\
\hline CD-IC & DC1I1_HÜMAN & $\begin{array}{l}\text { Destroys the cytoplasmatic dynein complex and stops dynein } \\
\text { dependent membrane motility }\end{array}$ & $\mathrm{DSGD}^{116}$ \\
\hline Cortactin & Q96H99_HUMAN & Putative: disruption of cytoskeletal reorganisation & Unknown \\
\hline Desmocollin-3 & DSC3_HUMAN & Putative: loss of cell-cell contact & Unknown \\
\hline Desmoglein-1 & DSG1_HUMAN & Decreased cell surface expression of desmoglein 1 & DLRD 888 \\
\hline Desmoglein-3 & DSG3_HUMAN & Putative: loss of cytoskeleton structure and cell-cell contact & DYAD ${ }^{781}$ \\
\hline $\begin{array}{l}\text { Desmoplakin } \\
\text { DLG1 }\end{array}$ & $\begin{array}{l}\text { DESP_HUMAN } \\
\text { DLG1_HUMAN }\end{array}$ & $\begin{array}{l}\text { Putative: loss of cytoskeleton structure and cell-cell contact } \\
\text { Putative: disruption of cell-cell contact }\end{array}$ & $\begin{array}{l}\text { Unknown } \\
\text { QSVD }^{427}\end{array}$ \\
\hline Dynactin-1 & DYNA_HUMAN & $\begin{array}{l}\text { Destroys the cytoplasmatic dynein complex and stops dynein } \\
\text { dependent membrane motility }\end{array}$ & Unknown \\
\hline E-cadherin & $\begin{array}{l}\text { CADH1_HUMAN/ } \\
\text { MOUSE }\end{array}$ & Release of intracellular fragment & $\mathrm{DTRD}^{750}$ \\
\hline $\mathrm{N}$-cadherin & CADH2_HUMAN & Putative: loss of cell adhesion & Unknown \\
\hline P-cadherin & CADH3_HUMAN & Possibly disruption of cell to cell contact & Unknown \\
\hline Emerin & EMD_HÜMAN & Putative: involved in nuclear envelope breakdown & Unknown \\
\hline Filamin-A & FLNA_HUMAN & Putative: disruption of cytoskeletal reorganisation & Unknown \\
\hline FAK & FAK1_HUMAN & Contributes to disassembly of focal adhesion complexes & $\mathrm{DQTD}^{772}$ \\
\hline Gas2 & GAS2_HUMAN & Regulation of microfilament and cell shape changes & $S_{R V D}^{37}$ \\
\hline$\gamma$-Catenin & Q86W21_HUMAN & Inactivated, involved in cell dismantling. Putative: loss of cell adhesion & Unknown \\
\hline Gelsolin & GELS_HŪMAN & $\begin{array}{l}\text { Loss of monomeric actin binding and triggering of F-actin } \\
\text { depolymerisation, membrane blebbing }\end{array}$ & $\mathrm{DQTD}^{403}$ \\
\hline Helicard & IFIH1_MOUSE & $\begin{array}{l}\text { C-terminal fragment accelerated DNA degradation. Putative: involved } \\
\text { in chromatin remodelling }\end{array}$ & DNTD $^{208}$, SCTD $^{251}$, SHRD $^{216}$ \\
\hline HIP-55 & DBNL_HUMAN & $\begin{array}{l}\text { Dissociates the actin binding from the } \mathrm{SH} 3 \text { domain, Putative: } \\
\text { cytoskeletal reorganisation }\end{array}$ & $\mathrm{EHID} \mathrm{D}^{361}$ \\
\hline HS1 & HCLS1_HUMAN & Putative: cytoskeletal reorganisation & Unknown \\
\hline Lamin A /C & LMNA_HUMAN & Breakdown of nuclear envelope & VEID 230 \\
\hline Lamin B1 & LMNB1_HUMAN & Nuclear lamina disassembly & VEID 231 \\
\hline Lamin B2 & LMNB2_HUMAN & Putative: nuclear lamina disassembly & Unknown \\
\hline LAP2- $\alpha$ & LAP2A_HUMAN & $\begin{array}{l}\text { Loss of chromatin association. Putative: detachment of chromatin } \\
\text { from the nuclear lamina }\end{array}$ & Unknown \\
\hline LBR & LBR_HUMAN & $\begin{array}{l}\text { N-terminal fragment relocalises to cytosol. Putative: nuclear lamina } \\
\text { disassembly }\end{array}$ & Unknown \\
\hline $\begin{array}{l}\text { Myosin heavy } \\
\text { chain }\end{array}$ & MYH2_HUMAN & Unknown & Unknown \\
\hline Myosin-14 & MYH14_HUMAN & Unknown & Unknown \\
\hline Myosin-9 & MYH9__HUMAN & Unknown & DTLD $^{1152}$ \\
\hline P-cadherin & CADH3_HUMAN & Possibly disruption of cell to cell contact & Unknown \\
\hline Plakophilin-1 & PKP1_HUMAN & Putative: loss of cytoskeleton structure and cell-cell contact & Unknown \\
\hline Plectin & PLEC̄1_HUMAN & Putative: reorganisation of microfilament system & ILRD $^{2395}$ \\
\hline CK-1 & ROCK1_HUMAN & $\begin{array}{l}\text { Constitutively activates kinase activity and drives cell contraction and } \\
\text { blebbing. }\end{array}$ & DETD $^{1113}$ \\
\hline$\alpha$-Spectrin & SPTA2_HUMAN & Disrupts cytoskeleton, possibly involved in membrane blebbing & DETD 1185 \\
\hline $\begin{array}{l}\beta \text {-Spectrin } \\
\text { erythroid }\end{array}$ & SPTB1_HUMAN & $\begin{array}{l}\text { Disruption of cortical cytoskeleton, possibly involved in membrane } \\
\text { blebbing }\end{array}$ & DSLD $^{1478}$, DEV \\
\hline$\beta$-Spectrin & SPTB2_HUMAN & Disrupts cytoskeleton, possibly involved in membrane blebbing & $\mathrm{DEVD}^{1457}$ \\
\hline SLK & SFRS9_HUMAN & $\begin{array}{l}\text { N-terminal fragment: kinase promotes cytoskeletal rearrangement. C- } \\
\text { terminal: disassembles actin fibres }\end{array}$ & Unknown \\
\hline Troponin T & TNNT2_HUMAN & Involvement in myofibrillar damage and contractile dysfunction & VDFD $^{96}$ \\
\hline$\alpha$-Tubulin 1 & TBA1_H̄UMAN & Unknown & Unknown \\
\hline Vimentin & VIME_HUMAN & Disrupts intermediate filaments, proapoptotic & DSVD $^{85}$, IDVD $^{259}$, TNLD $^{2}$ \\
\hline Vinculin & VINC_HUMAN & Putative: disruption of cytoskeletal assembly & Unknown \\
\hline VMLC1 & MYL3_HUMAN & Reduced myocyte contractile performance & DFVE $^{135}$ \\
\hline
\end{tabular}


Table 2 Caspase substrates: regulators of transcription/translation

\begin{tabular}{|c|c|c|c|}
\hline Name & UniProt & Consequences of caspase-dependant proteolysis (proposed) & Site(s) \\
\hline $\begin{array}{l}\text { AP2 } \alpha \\
\text { ATM }\end{array}$ & $\begin{array}{l}\text { AP2A_HUMAN } \\
\text { ATM_HUMAN }\end{array}$ & $\begin{array}{l}\text { Putative: loss of DNA binding capability, reduction in endocytosis } \\
\text { Loss of kinase activity. Fragment still binds DNA and acts as a } \\
\text { dominant-negative inhibitor }\end{array}$ & $\begin{array}{l}\mathrm{DRHD}^{19} \\
\text { DYPD }^{863}\end{array}$ \\
\hline BCAR1 & $\begin{array}{l}\text { BCAR1_HUMAN/ } \\
\text { MOUSE }\end{array}$ & $\begin{array}{l}\text { Overexpressed C-terminal fragment binds E2A and inhibits p21 } \\
\text { Cip transcription }\end{array}$ & $\mathrm{DSPD}^{650}$ \\
\hline BLM & BLM_HUMAN & $\begin{array}{l}\text { Interaction with topoisomerase } 3 \alpha \text { is impaired but the C-terminal } \\
\text { fragment retains helicase activity }\end{array}$ & TEVD $^{415}$ \\
\hline BTF3 & BTF3_HUMAN & Unknown & Unknown \\
\hline c-Rel & REL_HUMAN & Loss of transcriptional activity & Unknown \\
\hline CREB & CREB1_HUMAN & Putative: abolishes antiapoptotic effect & Unknown \\
\hline $\begin{array}{l}\text { Nuclear DNA } \\
\text { helicase II }\end{array}$ & DHX9_HUMAN & Putative reduction of transcription & EEVD $^{167}$ \\
\hline elF2a & IF2A_HUMAN & Putative: N-terminal fragment might not be phosphorylated by PKR & AEVD ${ }^{301}, \mathrm{DGDD}^{304}$ \\
\hline elF3 & IF3A_HUMAN & Unknown & DLAD 242, DYED 256 \\
\hline elF3S1 & IF31_HUMAN & Unknown & DSWD $15^{\prime}$ \\
\hline elF4B & IF4B_HUMAN & Loss of poly $(A)$-binding and translation & $\mathrm{DETD}^{45}$ \\
\hline elF4E type 3 & IF4E3_HUMAN & Unknown & TQKD 27 \\
\hline elF4E-BP1 & 4EBP1_HUMAN & Dominant-negative inhibitor of CAP-dependent translation & VLGD 25 \\
\hline elF4G 1 & IF4G1_HUMAN & Inhibition of translation & DLLD $^{492}$, DRLD $^{1136}$ \\
\hline elF4G 2 & IF4G2_HUMAN & $\begin{array}{l}\text { DAP } 5 \text { still binds to elF4A and elF3 and has an increased translation } \\
\text { from IRES sites }\end{array}$ & DETD $^{790}$ \\
\hline elF4G 3 & IF4G3_HUMAN & Dominant-negative inhibitor of CAP-dependant translation & Unknown \\
\hline elF4H & IF4H_HUMAN & Unknown & DEVD 92 \\
\hline FHOD1 & FHOD1_HUMAN & $\begin{array}{l}\text { Overexpressed C-terminal fragment translocates to nucleus and } \\
\text { inhibits transcription }\end{array}$ & SVPD $^{615}$ \\
\hline $\begin{array}{l}\text { FLI-1 } \\
\text { GATA-1 }\end{array}$ & $\begin{array}{l}\text { FLI1_MOUSE } \\
\text { GATA1_HUMAN }\end{array}$ & $\begin{array}{l}\text { Putative: loss of transcription factor function to ensure apoptosis } \\
\text { Loss of transcriptional activity which leads to impaired erythropoiesis }\end{array}$ & $\begin{array}{l}\text { SLFD }^{20}, \text { MEID }^{155}, \text { SHTD }^{209} \\
\text { EDLD }^{125}\end{array}$ \\
\hline Helicard & IFIH1_MOUSE & $\begin{array}{l}\text { Overexpressed C-terminal fragment translocates to the nucleus and } \\
\text { accelerated DNA degradation }\end{array}$ & DNTD $^{208}$, SCTD $^{251}$, SHRD $^{216}$ \\
\hline hnRNP AO & ROAO_HUMAN & Reduced RNA processing & HAVD $^{73}$ \\
\hline hnRNP A1 & ROA1_HUMAN & Unknown & Unknown \\
\hline hnRNP A2/B1 & ROA2_HUMAN & Reduced RNA processing & Unknown \\
\hline hnRNP A3 & ROA3_HUMAN & Reduced RNA processing & Unknown \\
\hline hnRNP C1/C2 & HNRPC_HUMAN & Unknown & Unknown \\
\hline hnRNP F & HNRPF_HUMAN & Unknown & Unknown \\
\hline hnRNP G & HNRPG_HUMAN & Unknown & Unknown \\
\hline hnRNP I & PTBP1_HUMAN & Reduced RNA processing & IVPD $^{7}$, AAVD $^{172}$ \\
\hline hnRNP K & HNRPK_HUMAN & Reduced RNA processing & Unknown \\
\hline hnRNP R & HNRPR_HUMAN & Reduced RNA processing & Unknown \\
\hline hnRNP U & HNRPU_HUMAN & Loss of DNA binding and translocation to cytoplasm & Unknown \\
\hline HSF & HSF1_HUMAN & Putative: loss of protective heat shock response & Unknown \\
\hline ICAD/DFF45 & DFFA_MOUSE & Release of active CAD endonuclease & DETD $^{117}$, DAVD $^{224}$ \\
\hline $\mathrm{La}$ & LA_HŪMAN & Putative: accumulation in nucleus and reduction of Pol III transcription & $\mathrm{DEHD}^{374}$ \\
\hline LEDGF & PSIP1_HUMAN & Loss of antiapoptotic function under conditions of serum starvation & EVPD $^{30}$, WEID $^{85}$, DAQD $^{486}$ \\
\hline Max & MAX_HUMAN & Higher DNA-binding affinity & IEVE $^{10}$, SAFD $^{135}$ \\
\hline MEF2A & MEF2̄A_HUMAN & Putative: reduced transcriptional activity & SSYD $^{466}$, STTD $^{215}$, TLTD $^{176}$ \\
\hline MEF2C & MEF2C_HUMAN & Putative: reduced transcriptional activity & SSYD 442 \\
\hline MEF2D & MEF2D_HUMAN & $\begin{array}{l}\text { Loss of the transactivation domain. Putative: reduced transcriptional } \\
\text { activity }\end{array}$ & LTED $^{288}$, DHLD $^{291}$ \\
\hline MCM 2 & MCM2_HUMAN & Putative: inhibition of replication & Unknown \\
\hline MCM 3 & MCM3_HUMAN & Putative: inhibition of replication & Unknown \\
\hline $\mathrm{NAC} \alpha$ & NACA_HUMAN & Unknown & Unknown \\
\hline $\mathrm{NF}-\kappa \mathrm{B}$ p50 & RELB_HUMAN & Loss of DNA binding & Unknown \\
\hline $\mathrm{NF}-\kappa \mathrm{B}$ p65 & TF65_HUMAN & Dominant-negative fragment, proapoptotic & Unknown \\
\hline NONO & NONO_HUMAN & Unknown & Unknown \\
\hline Nucleolin & NUCL_HUMAN & Unknown & Unknown \\
\hline NRF2 & NF2L2_HUMAN & Overexpressed C-terminal fragment is proapoptotic & TEVD ${ }^{208}$, EELD $^{366}$ \\
\hline PABP4 & PABP2_HUMAN & Unknown & VEGD 107 \\
\hline Pol $\varepsilon$ & DPOE1_HUMAN & Loss of catalytic subunit binding capability & $\mathrm{DQLD}^{216}, \mathrm{DEMD}^{1214}$ \\
\hline $\operatorname{RAR} \alpha$ & RARA_HUMAN & Loss of transcriptional activity & Unknown \\
\hline Relish & NFKB1_DROME & Putative: loss of transcriptional activity & Unknown \\
\hline $\mathrm{RHA}$ & DHX9_HUMAN & Putative reduction of transcription & EEVD $^{167}$ \\
\hline RIP-1 & RIPK1_HUMAN & Inhibits NF- $\kappa$ B activation & LQLD $^{324}$ \\
\hline SATB1 & SATB1_HUMAN & Putative: loss of transcriptional activity & Unknown \\
\hline Serum & SRF_HŪMAN & Putative: loss of DNA binding and loss of survival signalling & Unknown \\
\hline $\begin{array}{l}\text { response } \\
\text { factor }\end{array}$ & & & \\
\hline SnRNP70 & RU17_HUMAN & Reduced RNA processing & DGPD 341 \\
\hline SP1 & SP1_HUMAN & Loss of DNA binding & NSPD 590 \\
\hline $\begin{array}{l}\text { Splicing factor } \\
45\end{array}$ & SPF45_HUMAN & Unknown & TEKD 286 \\
\hline SREBP-1 & SRBP1_HUMAN & Unknown & SEPD $^{460}$ \\
\hline SREBP-2 & SRBP2_HUMAN & Unknown & DEPD $^{486}$ \\
\hline
\end{tabular}


Table 2 (Continued)

\begin{tabular}{|c|c|c|c|}
\hline Name & UniProt & Consequences of caspase-dependant proteolysis (proposed) & Site(s) \\
\hline SRP72 & $\begin{array}{l}\text { SRP72_HUMAN/ } \\
\text { MOUSE }\end{array}$ & Unknown & SELD $^{614}$ \\
\hline SSRP1 & SSRP1_HUMAN & $\begin{array}{l}\text { C-terminal fragment: loss of chromatin binding. Putative: impairment } \\
\text { of transcription/replication }\end{array}$ & $\mathrm{DQHD}^{450}$ \\
\hline STAT1 & STAT1_HUMAN & Blocks interferon and cytokine signalling & MELD 694 \\
\hline STAT3 & STAT3_HUMAN & $\begin{array}{l}\text { Reduced DNA binding and hence reduction in transcription factor } \\
\text { activity }\end{array}$ & Unknown \\
\hline $\begin{array}{l}\text { TAF6 } \\
\text { TRAF1 }\end{array}$ & $\begin{array}{l}\text { TAF6_HUMAN } \\
\text { TRAF1_HUMAN }\end{array}$ & $\begin{array}{l}\text { Alteration of transcription of gadd } 45 \text { and } \mathrm{p} 21 \\
\text { Inhibits NF- } \kappa \text { B activation, proapoptotic }\end{array}$ & $\begin{array}{l}\text { Unknown } \\
\text { LEVD }^{163}\end{array}$ \\
\hline Vav-1 & VAV_HUMAN & Reduced activation of AP- $1, N F-\kappa B, N F-A T, p 38$ but not JNK & DQID $^{150}$, DLYP $^{161}$ \\
\hline
\end{tabular}

Table 3 Caspase substrates: kinases and signalling intermediaries

\begin{tabular}{|c|c|c|c|}
\hline Name & UniProt & Consequences of caspase-dependant proteolysis (proposed) & Site(s) \\
\hline $\begin{array}{l}\text { AKT } \\
\text { Bid } \\
\text { BMX }\end{array}$ & $\begin{array}{l}\text { AKT1_HUMAN } \\
\text { BID_HUMAN } \\
\text { BMX_HUMAN }\end{array}$ & $\begin{array}{l}\text { Loss of kinase activity, Putative: loss of survival signalling } \\
\text { Translocates to mitochondria and induces apoptosis through MOMP } \\
\text { Increased kinase activity and proapoptotic upon overexpression of } \\
\text { cleaved fragment }\end{array}$ & $\begin{array}{l}\text { ECVD }^{462}, \text { TVAD }^{108}, \text { EEMD }^{119} \\
\text { LQTD }^{59}, \text { IEAD }^{74} \\
\text { DFPD }^{242}\end{array}$ \\
\hline CaMKII- $\alpha$ & KCC2A_RAT & Unknown & Unknown \\
\hline CaMKIV & KCC4_M̄MUSE & Loss of kinase activity & PAPD $^{176}$ \\
\hline CaMKLK & $\begin{array}{l}\text { MP2K1_HUMAN / } \\
\text { MOUSE }\end{array}$ & $\begin{array}{l}\mathrm{N} \text {-terminal fragment is proapoptotic, C-terminal fragment loses kinase } \\
\text { activity }\end{array}$ & $\mathrm{DEND}^{62}$ \\
\hline PPP3CA & PP2BA_HUMAN & $\begin{array}{l}\text { Constitutively active phosphatase which triggers NF-AT activation } \\
\text { and IL-2 release }\end{array}$ & DFGD ${ }^{386}$ \\
\hline Cdc42 & CDC42_HUMAN & Overexpression of non-cleavable mutant is antiapoptotic & DLRD $^{121}$ \\
\hline Claspin & CLSPN_HUMAN & $\begin{array}{l}\text { C-terminal fragment inhibits Chk1 phosphorylation and checkpoint } \\
\text { signalling }\end{array}$ & DEYD $^{1072}$ \\
\hline CDK inhibitor 1 & CDN1A_HUMAN & $\begin{array}{l}\text { Reduced association with cyclin-cdk2 complexes and increased cdk2 } \\
\text { activity }\end{array}$ & $\mathrm{DHVD}^{112}$ \\
\hline$\rho$-GDI 2 & GDIS_HUMAN & Translocation to nucleus. Loss of $\rho$ - GTPase signalling & DELD ${ }^{19}$ \\
\hline DNA-PKCs & PRKDC_HUMAN & Loss of catalytic protein kinase activity & DEVD 2713 \\
\hline EGF-R & EGFR_H̄UMAN & $\begin{array}{l}\text { Impaired tyrosine phosphorylaion of PLC- } \gamma 1 \text { and hence impaired } \\
\text { survival signalling }\end{array}$ & Unknown \\
\hline ErbB-2 & ERBB2_HUMAN & Putative: loss of kinase activity & SETD $^{1125}$, DVFD $^{1087}$ \\
\hline Fyn & FYN_HŪMAN & Relocalisation and increased kinase activity & $\mathrm{EERD}^{19}$ \\
\hline GrpL/Gads & GRAP2_HUMAN & Desensitisation of antigen receptor signalling & DIND $^{235}$ \\
\hline HEF1 & CASL_HUMAN & Putative: disrupts antiapoptotic integrin signalling & DLVD $^{363}$, DDYD $^{630}$ \\
\hline HPK-1 & M4K1_MOUSE & Increased kinase activity & DDVD 385 \\
\hline IPLA2 & PA2G6_HUMAN & $\begin{array}{l}\text { Increased phospholipid turnover, release of LPC which attracts } \\
\text { monocytic cells }\end{array}$ & DVTD $^{183}$ \\
\hline IRS-1 & IRS1_HUMAN & Putative: suppresses IGF-mediated survival signalling & Unknown \\
\hline IRS-2 & IRS2_HUMAN & Putative: suppresses IGF-mediated survival signalling & Unknown \\
\hline Kinectin & KTN1_HUMAN & Putative: disruption of the membrane trafficking pathway & Unknown \\
\hline Lyn & LYN_HUMAN & Relocalisation and increased kinase activity & $\mathrm{DGVD}^{18}$ \\
\hline MEK & MP2K1_MOUSE & Reduced Erk1/2 phosphorylation & Unknown \\
\hline MEKK1 & M3K1_MOUSE & Increased kinase activity & DTVD $^{874}$ (not conserved) \\
\hline Mst1 & STK4_HUMAN & Kinase constitutive active. & $\mathrm{DEMD}^{326}$ \\
\hline Mst2 & STK3_HUMAN & Kinase constitutive active & $\mathrm{DELD}^{322}$ \\
\hline Mst3 & STK24_HUMAN & Kinase constitutive active. & $\mathrm{AETD}^{313}$ \\
\hline p27 Kip1 & CDN1B_HUMAN & Reduced binding to cyclin cdk2 and increased cdk2 activity & $\mathrm{DPSD}^{139}, \mathrm{ESQD}^{108}$ \\
\hline PAK2 & PAK2_HUMAN & $\begin{array}{l}\text { Kinase constitutive active and activates c-Jun } \mathrm{N} \text {-terminal kinase } \\
\text { pathway. }\end{array}$ & SHVD 212 \\
\hline PDE6 & PDE6A_HUMAN & Reduced cGMP-hydrolyzing activity & Unknown \\
\hline $\begin{array}{l}\text { Phosphorylase } \\
\text { b kinase }\end{array}$ & KPB1_HUMAN & Putative: slight increased phoshphorylase activity & $\mathrm{DWMD}^{646}$ \\
\hline $\operatorname{PKC} \delta$ & KPCD_HUMAN & $\begin{array}{l}\text { Kinase constitutive active. Proapoptotic upon overexpression of } \\
\text { fragment }\end{array}$ & $\mathrm{DMQD}^{329}$ \\
\hline $\mathrm{PKC} \varepsilon$ & $\begin{array}{l}\text { KPCE_HUMAN/ } \\
\text { MOUSE }\end{array}$ & Kinase constitutive active & $\mathrm{SSPD}^{383} / \mathrm{SATD}^{383}$ \\
\hline $\mathrm{PKC} \eta$ & KPCL_HUMAN & $\begin{array}{l}\text { Kinase constitutive active. Proapoptotic upon overexpression of } \\
\text { fragment }\end{array}$ & Unknown \\
\hline PKC $\mu$ & KPCD1_HUMAN & Increased sensitivity to genotoxic stress & CQND 378 \\
\hline PKC $\theta$ & $\begin{array}{l}\text { KPCT_HUMAN/ } \\
\text { MOUSE }\end{array}$ & Kinase constitutive active. & $\mathrm{DEVD}^{354} / \mathrm{DDND}^{355}, \mathrm{DQED}^{397}$ \\
\hline $\mathrm{PKC} \zeta$ & KPCZ_HUMAN & Kinase constitutive active & EETD $^{210}, \mathrm{DGVD}^{239}$ \\
\hline PKR & E2AK2_HUMAN & $\begin{array}{l}\text { Kinase constitutive active, phosphorylates elF2a which leads to } \\
\text { translational inhibition }\end{array}$ & DLPD $^{251}$ \\
\hline PLC $\gamma 1$ & PLCG1_HUMAN & Facilitates apoptosis & AEPD $^{770}$ \\
\hline PMCA4 & AT2B4_HUMAN & Conflicting reports. Enzyme activity is lost or kept & Unknown \\
\hline
\end{tabular}


Table 3 (Continued)

\begin{tabular}{|c|c|c|c|}
\hline Name & UniProt & Consequences of caspase-dependant proteolysis (proposed) & Site(s) \\
\hline $\begin{array}{l}\text { PP2A } \\
\text { PPP3CA }\end{array}$ & $\begin{array}{l}\text { 2AAA_HUMAN } \\
\text { PP2BA_HUMAN }\end{array}$ & $\begin{array}{l}\text { Increased phosphatase activity } \\
\text { Constitutively active phosphatase which triggers NF-AT activation } \\
\text { and IL-2 release }\end{array}$ & $\begin{array}{l}\text { DEQD }^{218} \\
\text { DFGD }^{386}\end{array}$ \\
\hline PRK1 & PKN1_HUMAN & Kinase constitutive active & Unknown \\
\hline pro-IL-16 & IL16_HUMAN & Induces T-cell chemotaxis & SSTD $^{510}$ \\
\hline pro-IL-18 & IL18_HUMAN & Activates IL-18 and induces IFN- $\gamma$ production & LESD $^{36}$ \\
\hline pro-IL-1 $\beta$ & IL1B_HUMAN & Activated IL- $1 \beta$ and Induces inflammatory response & YVHD ${ }^{116}$ \\
\hline pro-IL-33 & IL33_HUMAN & Putative: Activated IL-33 which sensitises towards a $\mathrm{TH} 2$ response & Unknown \\
\hline Rabaptin-5 & RABE1_HUMAN & Block of endosome fusion & $\mathrm{DESD}^{438}$ \\
\hline Raf-1 & RAF1_HUMAN & $\begin{array}{l}\text { Overexpressed } \mathrm{C} \text { terminus translocates to mitochondrial fraction and } \\
\text { has a higher enzymatic activity }\end{array}$ & Unknown \\
\hline Ran-GAP1 & RGP1_HUMAN & Putative: altered nuclear pore transport & DEGD $^{157}$, DTVD $^{459}$ \\
\hline Ras-GAP & RASA'1_HUMAN & $\begin{array}{l}\text { Low-caspase activity generates antiapoptotic } \mathrm{N} \text { terminus. High- } \\
\text { caspase activity generates proapoptic fragments }\end{array}$ & $\mathrm{DTVD}^{455}, \mathrm{DEGD}^{157}$ \\
\hline RET & RET_HUMAN & Proapoptotic & VSVD $^{707}$, DYLD $^{1017}$ \\
\hline$\rho$-GDI 2 & GDIS_HUMAN & Translocation to nucleus. Loss of $\rho$ - GTPase signalling & DELD 19 \\
\hline ROCK 1 & ROCK1_HUMAN & $\begin{array}{l}\text { Constitutively activates kinase activity and drives cell contraction and } \\
\text { blebbing. }\end{array}$ & DETD 1113 \\
\hline SLK & SLK_HUMAN & Unknown & Unknown \\
\hline SPAK & $\begin{array}{l}\text { STK39_HUMAN/ } \\
\text { MOUSE }\end{array}$ & $\begin{array}{l}\text { Removal of substrate binding domain. Downregulation sensitises to } \\
\text { apoptosis }\end{array}$ & Murine: ANED ${ }^{455}$, DTAD $^{491}$ \\
\hline Src & SRC_HUMAN & Putative: loss of antiapoptotic signalling downstream of EGFR & Unknown \\
\hline SRPK1 & SRPK̄1_HUMAN & Decreased kinase activity & Unknown \\
\hline SRPK2 & SRPK2_HUMAN & Decreased kinase activity & Unknown \\
\hline STAT1 & STAT1_HUMAN & Blocks interferon and cytokine signalling & MELD 694 \\
\hline SLK & SFRS9_HUMAN & $\begin{array}{l}\mathrm{N} \text { terminus: kinase promotes apoptosis and cytoskeletal } \\
\text { rearrangement. } \mathrm{C} \text { terminus: disassembles actin fibres }\end{array}$ & Unknown \\
\hline $\begin{array}{l}\text { TCR } \zeta \text { chain } \\
\text { precursor }\end{array}$ & CD3Z_HUMAN & Putative: degradation of protein & GLLD $^{28}$ or YLLD ${ }^{36}$,DTYD ${ }^{153}$ \\
\hline TNF-R1 & TNR1A_HUMAN & Unknown & Unknown \\
\hline TRAF1 & TRAF1_HUMAN & Inhibits NF- $\kappa$ B activation, proapoptotic & LEVD $^{163}$ \\
\hline TRAF3 & TRAF3_HUMAN & Altered cellular distribution & EEAD $^{348}$, ESVD $^{368}$ \\
\hline $\begin{array}{l}\text { Tax1-binding } \\
\text { protein } 1\end{array}$ & TAXB1_HUMAN & Loss of antiapoptotic effect & Unknown \\
\hline Wee1 & WEE1_HUMAN & $>20$-fold reduction of kinase activity & Unknown \\
\hline
\end{tabular}

identified was the internucleosomal scission of DNA into multiples of approximately $200 \mathrm{bp},{ }^{43}$ an event that is also under the control of caspases. Caspase inhibitors very efficiently block this extensive DNA hydrolysis, apparently through delaying the caspase-3 -mediated inactivation of inhibitor caspase-activated DNase (ICAD)/DNA fragmentation factor (DFF)45, the inhibitory subunit of the caspaseactivated DNase (CAD)/DFF40 nuclease. ${ }^{52,53}$ Multiple transcription factors are also cleaved by caspases and a range of translation initiation factors and ribosomal proteins are also affected (see Table 2). Predictably, this results in transcriptional and translation shut down relatively early in the process. Similar to DNA hydrolysis during apoptosis, it is not clear why the transcriptional and translational machineries are targeted by caspases. A plausible explanation is that this may guard against the possibility that these machineries could be used to replicate viruses that might have provoked apoptosis in the first place. Similarly, apoptosis-associated DNA hydrolysis may also safeguard against the persistence of viral DNA. Alternatively, the latter event may simply render chromatin more manageable for subsequent removal by phagocytes.

Numerous kinases and other signaling intermediaries have also been reported to be cleaved by caspases during apoptosis (see Table 3). In many cases, this results in the production of constitutively active forms of such kinases but, with the exception of ROCK I as discussed above, it is likely that many of these events are not especially relevant for apoptosis.
A major goal of programmed cell death is to facilitate the swift clearance of dying cells while avoiding release of cellular contents. A number of alterations to the composition of the membranes of apoptotic cells have been documented, ${ }^{54}$ perhaps the most well known of which is the externalisation of phosphatidylserine on the outer leaflet of the plasma membrane. ${ }^{55}$ Although this event is also blocked by inhibition of caspase activity, ${ }^{56}$ it remains unclear how phosphatidylserine externalisation or other apoptosis-associated membrane events, is regulated by caspases. In addition to becoming licensed for removal by phagocytes, apoptotic cells may also actively attract the attentions of such cells by secreting molecules with chemotactic properties. This may occur through the caspase-dependent release of a chemoattractant lipid, lysophosphatidylcholine (LPC), possibly mediated by cleavage and activation of calcium independent phospholipase A (iPLA) by caspase-3 (Figure 2). ${ }^{57}$

\section{Concluding Remarks}

The knowledge that there are in excess of 400 proteins that become targeted for proteolysis by caspases during the terminal phase of apoptosis suggests that we are still some way from fully understanding how these proteases coordinate this cell death paradigm. It seems rather unlikely that failure to cleave individual substrates is likely to have any impact on the kinetics of cell death in the great majority of cases. Rather, failure to cleave particular substrates may well alter certain 


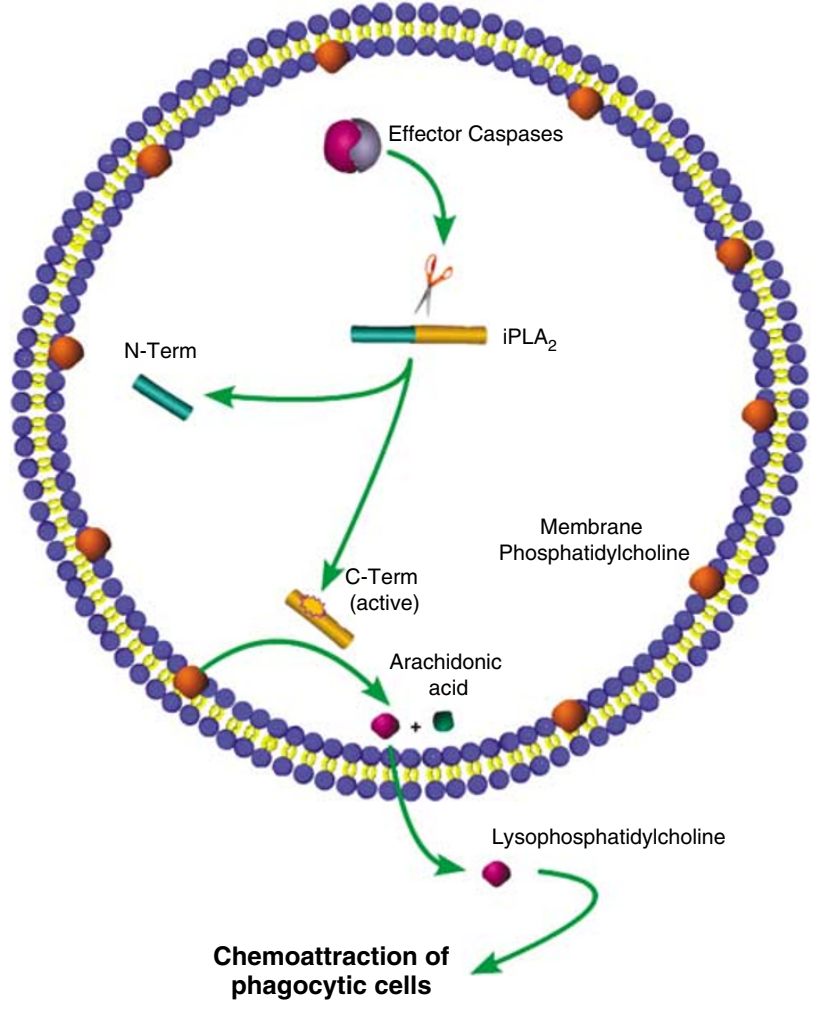

Figure 2 Caspases promote the release of chemotactic factors via iPLA2 Activated effector caspases cleave the calcium independent phospholipase $A_{2}$ resulting in a constitutively active $\mathrm{C}$-terminal fragment. Active iPLA ${ }_{2}$ hydrolyses membrane bound phosphatidylcholine to bioactive LPC and arachidonic acid. LPC is released from the cell to the extracellular space and acts as a chemoattractant for phagocytic cells, which engulf and remove the apoptotic cell

aspects of the apoptotic phenotype; a good example of which is the pronounced delay in the kinetics of DNA fragmentation upon disablement of the ICAD/CAD system. However, discovery of especially influential caspase substrates appears to be the exception rather than the rule, with the majority of substrates that have been reported to date playing relatively minor roles in the process. Owing to the sheer number of proteins that are cleaved by caspases during the throes of death, it has thusfar proved difficult to identify a subset of proteins that have particular relevance for the signature events that define apoptosis. Nonetheless, a blueprint for how caspases kill is slowly emerging from the dense thicket of caspase substrates that have been identified to date.

Acknowledgements. We are indebted to Science Foundation Ireland for their support of ongoing work in our laboratory. SJM is a Science Foundation Ireland Principal Investigator (PI1/B038)

1. Fuentes-Prior P, Salvesen GS. The protein structures that shape caspase activity, specificity, activation and inhibition. Biochem J 2004; 384: 201-232.

2. Adrain C, Brumatti G, Martin SJ. Apoptosomes: protease activation platforms to die from Trends. Biochem Sci 2006; 31: 243-247.

3. Martin SJ. Destabilizing influences in apoptosis: sowing the seeds of IAP destruction. Cell 2002; 109: 793-796.
4. Slee EA, Harte MT, Kluck RM, Wolf BB, Casiano CA, Newmeyer DD et al. Ordering the cytochrome c-initiated caspase cascade: hierarchical activation of caspases-2, -3, -6, -7, -8 , and -10 in a caspase-9-dependent manner. J Cell Biol 1999; 144: 281-292.

5. Sun XM, MacFarlane M, Zhuang J, Wolf BB, Green DR, Cohen GM. Distinct caspase cascades are initiated in receptor-mediated and chemical-induced apoptosis. J Biol Chem 1999; 274: 5053-5060.

6. Rehm M, Dussmann H, Janicke RU, Tavare JM, Kogel D, Prehn JH. Single-cell fluorescence resonance energy transfer analysis demonstrates that caspase activation during apoptosis is a rapid process Role of caspase-3. J Biol Chem 2002; 277: 2450624514

7. Schmitz J, Owyang A, Oldham E, Song Y, Murphy E, McClanahan TK et al. IL-33, an interleukin-1-like cytokine that signals via the IL-1 receptor-related protein ST2 and induces Thelper type 2-associated cytokines. Immunity 2005; 23: 479-490.

8. Zimmermann KC, Ricci JE, Droin NM, Green DR. The role of ARK in stress-induced apoptosis in Drosophila cells. J Cell Biol 2002; 156: 1077-1087.

9. Leist M, Jaattela M. Triggering of apoptosis by cathepsins. Cell Death Differ 2001; 8: 324-326.

10. Egger L, Schneider J, Rheme C, Tapernoux M, Hacki J, Borner C. Serine proteases mediate apoptosis-like cell death and phagocytosis under caspase-inhibiting conditions. Cell Death Differ 2003; 10: 1188-1203.

11. Chipuk JE, Green DR. Do inducers of apoptosis trigger caspase-independent cell death? Nat Rev Mol Cell Biol 2005; 6: 268-275.

12. Kroemer G, Martin SJ. Caspase-independent cell death. Nat Med 2005; 11: 725-730.

13. Adrain C, Martin SJ. The mitochondrial apoptosome: a killer unleashed by the cytochrome seas. Trends Biochem Sci 2001; 26: 390-397.

14. Deshmukh M, Kuida K, Johnson Jr EM. Caspase inhibition extends the commitment to neuronal death beyond cytochrome $c$ release to the point of mitochondrial depolarization. J Cell Biol 2000; 150: 131-143.

15. Potts MB, Vaughn AE, McDonough H, Patterson C, Deshmukh M. Reduced Apaf-1 levels in cardiomyocytes engage strict regulation of apoptosis by endogenous XIAP. J Cell Biol 2005; 171: 925-930.

16. Ellis HM, Horvitz HR. Genetic control of programmed cell death in the nematode C. elegans. Cell 1986; 44: 817-829.

17. Shaham S, Reddien PW, Davies B, Horvitz HR. Mutational analysis of the Caenorhabditis elegans cell-death gene ced-3. Genetics 1999; 153: 1655-1671.

18. Daish T, Harvey KF, Pfleger CM, Hariharan IK, Kumar S. The Drosophila melanogaster Apaf-1 homologue ARK is required for most, but not all, programmed cell death. J Cell Biol 2006; 172: 809-815.

19. Daish TJ, Mills K, Kumar S. Drosophila caspase DRONC is required for specific developmental cell death pathways and stress-induced apoptosis. Dev Cell 2004; 7: 909-915.

20. Chew SK, Akdemir F, Chen P, Lu WJ, Mills K, Daish T et al. The apical caspase dronc governs programmed and unprogrammed cell death in Drosophila. Dev Cell 2004; 7 : 897-907.

21. Xu D, Li Y, Arcaro M, Lackey M, Bergmann A. The CARD-carrying caspase Dronc is essential for most, but not all, developmental cell death in Drosophila. Development 2005; 132: 2125-2134.

22. Zheng TS, Hunot S, Kuida K, Flavell RA. Caspase knockouts: matters of life and death. Cell Death Differ 1999; 6: 1043-1053.

23. Los M, Wesselborg S, Schulze-Osthoff $K$. The role of caspases in development, immunity, and apoptotic signal transduction: lessons from knockout mice. Immunity 1999; 10: $629-639$.

24. Alvarez-Bolado G, Meyer BI, Roth KA, Gruss P. Apaf1 (CED-4 homolog) regulates programmed cell death in mammalian development. Cell 1998; 94: 727-737.

25. Janicke RU, Sprengart ML, Wati MR, Porter AG. Caspase-3 is required for DNA fragmentation and morphological changes associated with apoptosis. J Biol Chem 1998; 273: $9357-9360$

26. Li H, Zhu H, Xu CJ, Yuan J. Cleavage of BID by caspase 8 mediates the mitochondrial damage in the Fas pathway of apoptosis. Cell 1998; 94: 491-501.

27. Luo X, Budihardjo I, Zou H, Slaughter C, Wang X. Bid, a Bcl2 interacting protein, mediates cytochrome $\mathrm{c}$ release from mitochondria in response to activation of cell surface death receptors. Cell 1998; 94: 481-490.

28. Lin Y, Devin A, Rodriguez Y, Liu ZG. Cleavage of the death domain kinase RIP by caspase-8 prompts TNF-induced apoptosis. Genes Dev 1999; 13: 2514-2526.

29. Martinon F, Holler N, Richard C, Tschopp J. Activation of a pro-apoptotic amplification loop through inhibition of NF-kappaB-dependent survival signals by caspase-mediated inactivation of RIP. FEBS Lett 2000; 468: 134-136.

30. Janicke RU, $\mathrm{Ng} \mathrm{P}$, Sprengart ML, Porter AG. Caspase-3 is required for alpha-fodrin cleavage but dispensable for cleavage of other death substrates in apoptosis. J Biol Chem 1998; 273: 15540-15545.

31. Slee EA, Adrain C, Martin SJ. Executioner caspase-3, -6, and -7 perform distinct, non-redundant roles during the demolition phase of apoptosis. J Biol Chem 2001; 276: 7320-7326.

32. Thornberry NA, Rano TA, Peterson EP, Rasper DM, Timkey T, Garcia-Calvo M et al. A combinatorial approach defines specificities of members of the caspase family and granzyme B. Functional relationships established for key mediators of apoptosis. J Biol Chem 1997; 272: 17907-17911. 
33. Stennicke HR, Salvesen GS. Biochemical characteristics of caspases-3, $-6,-7$, and -8 . J Biol Chem 1997; 272: 25719-25723.

34. Kuida K, Zheng TS, Na S, Kuan C, Yang D, Karasuyama $\mathrm{H}$ et al. Decreased apoptosis in the brain and premature lethality in CPP32-deficient mice. Nature 1996; 384 368-372.

35. Houde C, Banks KG, Coulombe N, Rasper D, Grimm E, Roy S et al. Caspase-7 expanded function and intrinsic expression level underlies strain-specific brain phenotype of caspase3-null mice. J Neurosci 2004; 24: 9977-9984.

36. Zandy AJ, Lakhani S, Zheng T, Flavell RA, Bassnett S. Role of the executioner caspases during lens development. J Biol Chem 2005; 280: 30263-30272.

37. Lakhani SA, Masud A, Kuida K, Porter Jr GA, Booth CJ, Mehal WZ et al. Caspases 3 and 7 : key mediators of mitochondrial events of apoptosis. Science 2006; 311: 847-851.

38. Lazebnik YA, Takahashi A, Moir RD, Goldman RD, Poirier GG, Kaufmann SH et al. Studies of the lamin proteinase reveal multiple parallel biochemical pathways during apoptotic execution. Proc Natl Acad Sci USA 1995; 92: 9042-9046.

39. Takahashi A, Alnemri ES, Lazebnik YA, Fernandes-Alnemri T, Litwack G, Moir RD et al. Cleavage of lamin A by Mch2 alpha but not CPP32: multiple interleukin 1 beta-converting enzyme-related proteases with distinct substrate recognition properties are active in apoptosis. Proc Natl Acad Sci USA 1996; 93: 8395-8400.

40. Cowling V, Downward J. Caspase- 6 is the direct activator of caspase-8 in the cytochrome c-induced apoptosis pathway: absolute requirement for removal of caspase- 6 prodomain. Cell Death Differ 2002; 9: 1046-1056.

41. Murphy BM, O'Neill AJ, Adrain C, Watson RW, Martin SJ. The apoptosome pathway to caspase activation in primary human neutrophils exhibits dramatically reduced requirements for cytochrome C. J Exp Med 2003; 197: 625-632.

42. Kerr JF, Wyllie AH, Currie AR. Apoptosis: a basic biological phenomenon with wide-ranging implications in tissue kinetics. Br J Cancer 1972; 26: 239-257.

43. Wyllie AH. Glucocorticoid-induced thymocyte apoptosis is associated with endogenous endonuclease activation. Nature 1980; 284: 555-556.

44. McCarthy NJ, Whyte MK, Gilbert CS, Evan G. Inhibition of Ced-3/ICE-related proteases does not prevent cell death induced by oncogenes, DNA damage, or the Bcl-2 homologue Bak. J Cell Biol 1997; 136: 215-227.

45. Susin SA, Daugas E, Ravagnan L, Samejima K, Zamzami N, Loeffler M et al. Two distinct pathways leading to nuclear apoptosis. J Exp Med 2000; 192: 571-580.
46. Coleman ML, Sahai EA, Yeo M, Bosch M, Dewar A, Olson MF. Membrane blebbing during apoptosis results from caspase-mediated activation of ROCK I. Nat Cell Biol 2001; 3: 339-345.

47. Croft DR, Coleman ML, Li S, Robertson D, Sullivan T, Stewart CL et al. Actin-myosinbased contraction is responsible for apoptotic nuclear disintegration. J Cell Biol 2005; 168 245-255.

48. Rao L, Perez D, White E. Lamin proteolysis facilitates nuclear events during apoptosis J Cell Biol 1996; 135: 1441-1455.

49. Sebbagh M, Renvoize C, Hamelin J, Riche N, Bertoglio J, Breard J. Caspase-3-mediated cleavage of ROCK I induces MLC phosphorylation and apoptotic membrane blebbing. Nat Cell Biol 2001; 3: 346-352.

50. Mills JC, Stone NL, Erhardt J, Pittman RN. Apoptotic membrane blebbing is regulated by myosin light chain phosphorylation. J Cell Biol 1998; 140: 627-636.

51. Cotter TG, Lennon SV, Glynn JM, Green DR. Microfilament-disrupting agents prevent the formation of apoptotic bodies in tumor cells undergoing apoptosis. Cancer Res 1992; 52 997-1005

52. Liu X, Zou $H$, Slaughter $C$, Wang X. DFF, a heterodimeric protein that functions downstream of caspase-3 to trigger DNA fragmentation during apoptosis. Cell 1997; 89 175-184.

53. Woo M, Hakem R, Soengas MS, Duncan GS, Shahinian A, Kagi D et al. Essential contribution of caspase 3/CPP32 to apoptosis and its associated nuclear changes. Genes Dev 1998; 12: 806-819.

54. Savill J, Dransfield I, Gregory C, Haslett C. A blast from the past: clearance of apoptotic cells regulates immune responses. Nat Rev Immunol 2002; 2: 965-975.

55. Martin SJ, Reutelingsperger CP, McGahon AJ, Rader JA, van Schie RC, LaFace DM et al. Early redistribution of plasma membrane phosphatidylserine is a general feature of apoptosis regardless of the initiating stimulus: inhibition by overexpression of $\mathrm{Bcl}-2$ and $\mathrm{Abl}$. $J$ Exp Med 1995; 182: 1545-1556.

56. Martin SJ, Finucane DM, Amarante-Mendes GP, O'Brien GA, Green DR Phosphatidylserine externalization during CD95-induced apoptosis of cells and cytoplasts requires ICE/CED-3 protease activity. J Biol Chem 1996; 271: 28753-28756.

57. Lauber K, Bohn E, Krober SM, Xiao YJ, Blumenthal SG, Lindemann RK et al. Apoptotic cells induce migration of phagocytes via caspase-3-mediated release of a lipid attraction signal. Cell 2003; 113: 717-730.

\section{Supplementary Information accompanies the paper on Cell Death and Differentiation website (http://www.nature.com/cdd)}

